\title{
A novel uPAg-KPI fusion protein inhibits the growth and invasion of human ovarian cancer cells in vitro
}

\author{
LI-PING ZHAO $^{1 *}$, TIAN-MIN XU $^{1 *}$, MU-JIE KAN ${ }^{2}$, YE-CHEN XIAO $^{2}$ and MAN-HUA CUI ${ }^{1}$ \\ ${ }^{1}$ Department of Gynecology and Obstetrics, The Second Hospital of Jilin University, Changchun, Jilin 130041; \\ ${ }^{2}$ Department of Biochemistry and Molecular Biology, College of Basic Medical Science, \\ Jilin University, Changchun, Jilin 130021, P.R. China
}

Received September 2, 2015; Accepted March 17, 2016

DOI: $10.3892 /$ ijmm.2016.2540

\begin{abstract}
Urokinase-type plasminogen activator (uPA) acts by breaking down the basement membrane and is involved in cell proliferation, migration and invasion. These actions are mediated by binding to the uPA receptor (UPAR) via its growth factor domain (GFD). The present study evaluated the effects of uPAg-KPI, a fusion protein of uPA-GFD and a kunitz protease inhibitor (KPI) domain that is present in the amyloid $\beta$-protein precursor. Using SKOV-3 cells, an ovarian cancer cell line, we examined cell viability, migration, invasion and also protein expression. Furthermore, we examined wound healing, and migration and invasion using a Transwell assay. Our data showed that uPAg-KPI treatment reduced the viability of ovarian cancer SKOV-3 cells in both a concentration and time-dependent manner by arresting tumor cells at $\mathrm{G} 1 / \mathrm{G} 0$ phase of the cell cycle. The $\mathrm{IC}_{50}$ of uPAg-KPI was $0.5 \mu \mathrm{g} / \mu \mathrm{l}$ after $48 \mathrm{~h}$ treatment. At this concentration, uPAg-KPI also inhibited tumor cell colony formation, wound closure, as well as cell migration and invasion capacity. At the protein level, western blot analysis demonstrated that uPAgKPI exerted no significant effect on the expression of total extracellular signal-regulated kinase (ERK)1/ERK2 and AKT, whereas it suppressed levels of phosphorylated ERK1/ERK2 and AKT. Thus, we suggest that this novel uPAg-KPI fusion protein reduced cell viability, colony formation, wound healing and the invasive ability of human ovarian cancer SKOV-3 cells in vitro by regulating ERK and AKT signaling. Further studies using other cell lines will confirm these findings.
\end{abstract}

Correspondence to: Professor Man-Hua Cui, Department of Gynecology and Obstetrics, The Second Hospital of Jilin University, 218 Ziqiang Street, Changchun, Jilin 130041, P.R. China

E-mail: cuimanhua@126.com

${ }^{*}$ Contributed equally

Key words: ovarian cancer, urokinase-type plasminogen activator, kunitz protease inhibitor, fusion protein, antitumor activity

\section{Introduction}

Ovarian cancer is a significant health problem worldwide, accounting for more than 200,000 new cases of cancer and 125,000 cancer-related deaths each year. Furthermore, ovarian cancer is ranked as the sixth most common cancer and seventh most common cause of mortality for women (1). Despite recent advancements in the prevention, detection and treatment of ovarian cancer, it remains the cause of the highest number of gynecological-related mortalities in Western countries. This is thought to be due to late diagnosis, thereby reducing treatment options (stages III-IV) (2). As a result of this situation, novel treatments and earlier diagnostic tools are urgently required in order to effectively target ovarian cancer.

In ovarian cancer, similar to other cancers, tumor metastasis has been shown to be responsible for a significant number of mortalities, and tumor cell invasion is dependent on finely regulated extracellular proteolytic activity, which allows tumor cells to invade the extracellular matrix (3). Urokinasetype plasminogen activator (uPA) breaks down the basement membrane upon binding to the uPA receptor (UPAR) through the respective growth factor domain (GFD) (4). Thus, the activated $\mathrm{uPA} / \mathrm{uPAR} /$ plasmin proteolytic cascade plays a key role in tumor invasion and the dissemination of various malignancies $(5,6)$. In addition to its recognized function in extracellular matrix degradation, uPA signaling has been implicated in tumor cell proliferation, migration and the invasion of local tissues (4). However, it has been hypothesized that downregulation of UPA and UPAR, blockade of UPA activity using an antibody or small molecule inhibitor, or interfering with uPA binding to its receptor could suppress the promotion of cell mobility and growth. This approach is considered to be a novel method in treating tumors. Indeed, certain of these potential approaches have demonstrated potent anticancer effects and are currently being further evaluated in clinical trials (7-10) (http://www. wilex.de/portfolio/mesupron/phase-i-mit-wx-uk1/).

In cases of ovarian cancer, the expression of uPA and UPAR has been associated with epithelial ovarian cancer progression $(11,12)$. Previously, it has been demonstrated that high levels of expression of uPA are associated with residual tumor progression in ovarian cancer patients, suggesting that targeting uPA signaling helps clinicians to stratify patients (13). Thus, in the present study, we constructed and expressed a fusion protein, 
uPAg-kunitz protease inhibitor (KPI). This involved fusing uPA GFD with KPI, a kunitz protease inhibitor domain that is found in amyloid beta-protein precursor (APP). Incorporation of the KPI-amyloid protein precursor allowed for inhibition of serine protease hydrolysis (14). Subsequently, we assessed uPAg-KPI antitumor activity in ovarian cancer cells in vitro. Our previous study expressed uPAg-KPI in Pichia pastoris, and used ion exchange chromatography to purify the target protein. Renaturalization was carried out using ammonium sulfate, and biological analysis demonstrated that this fusion protein inhibited serine protease activity (15). The present study provides insightful information in relation to the effect of uPAg-KPI regulation on ovarian cancer cell viability, migration and invasion in vitro.

\section{Materials and methods}

Chemicals and reagents. 3-(4,5-dimethylthiazol-2-yl)-2,5-diphenyltetrazolium bromide (MTT) and dimethyl sulfoxide (DMSO) were both purchased from Sigma (St. Louis, MO, USA), and the BrdU Flow kit and Biocoat Matrigel ${ }^{\mathrm{TM}}$ invasion inserts were both purchased from BD Biosciences (San Jose, CA, USA). The Transwell chamber was from Corning (Corning, NY, USA), and Iscove's modified Dulbecco's medium (IMDM) and fetal bovine serum (FBS) were both from HyClone (Logan, UT, USA). Crystal violet, Trypan blue, penicillin-streptomycin and trypsin-EDTA were all purchased from Solarbio (Beijing, China), and the primary antibodies used for western blot analysis of p-extracellular signal-regulated kinase (ERK; 4695), p-ERK (9101), AKT (9272) and p-AKT (4058) were all purchased from Cell Signaling Technology (Danvers, MA, USA). uPAg-KPI was constructed and prepared in the College of Pharmacy, Biological Engineering Laboratory (Jilin University, Changchun, China), it was expressed in Pichia pastoris, by renaturation and ion exchange chromatography; biological analysis demonstrated that the fusion protein inhibited serine protease activity, as previously described (15).

Human ovarian adenocarcinoma cell line and culture. The human ovarian adenocarcinoma cell line SKOV-3 was obtained from Biochemical Teaching and Research Section, Basic Medical Institute, Jilin University (Changchun, China) and cultured in IMDM supplemented with $10 \%$ FBS, $100 \mathrm{U} / \mathrm{ml}$ penicillin, and $100 \mu \mathrm{g} / \mathrm{ml}$ streptomycin in a humidified incubator with $5 \% \mathrm{CO}_{2}$ and $95 \%$ air at $37^{\circ} \mathrm{C}$.

Cell viability MTT assay. SKOV-3 cells were seeded and grown on a 96-well plate with a flat bottom at a density of 5,000 cells/well in complete medium supplemented with $10 \%$ FBS for $24 \mathrm{~h}$. Following incubation, the wells were treated with $0,0.05,0.1,0.5$ and $1.0 \mu \mathrm{g} / \mu \mathrm{l}$ of $\mathrm{uPAg}-\mathrm{KPI}$, respectively for up to $72 \mathrm{~h}$. At the end of each experiment, $20 \mu \mathrm{l} \mathrm{MTT}$ solution $(5 \mathrm{mg} / \mathrm{ml})$ was added and cells were further incubated for $4 \mathrm{~h}$ at $37^{\circ} \mathrm{C}$. Following this, cell medium was replaced with $100 \mu \mathrm{l} /$ well DMSO and optical density (A490 nm) was read on an automated microplate reader (BioTek, Winooski, VT, USA). The data were calculated as the means \pm SD.

Flow cytometric cell cycle distribution assay. To analyze cell cycle distribution, cells were cultured overnight in serum-free
IMDM overnight and in IMDM-containing 10\% FBS for treatment with $0.5 \mu \mathrm{g} / \mu \mathrm{l}$ concentration of $\mathrm{uPAg}$-KPI for $48 \mathrm{~h}$. BrdU was then added $(10 \mu \mathrm{l} / \mathrm{ml})$ to cell cultures for an additional $0.5 \mathrm{~h}$. Cells were then collected by trypsinization, fixed in a Cytofix/Cytoperm buffer and Cytoperm-plus buffer in the dark, and then washed in a Perm/Wash buffer, and digested with RNase (all from BD Biosciences) for $1 \mathrm{~h}$ at $37^{\circ} \mathrm{C}$. The resulting solution was resuspended in $1 \mathrm{ml}$ of Perm/Wash buffer and stained with $0.01 \mathrm{mg} / \mathrm{ml}$ of propidium iodide in the dark for $30 \mathrm{~min}$ at room temperature. Cells were analyzed using a flow cytometer (BD Accuri C6; BD Biosciences).

Colony formation assay. Cells at a density of 200 cells/well were added to 6-well plates and cultured in IMDM containing $10 \% \mathrm{FBS}$ in triplicate for $12 \mathrm{~h}$ and then treated with uPAg-KPI $(0.5 \mu \mathrm{g} / \mu \mathrm{l})$ at $37^{\circ} \mathrm{C}$ for 14 days. Following treatment, cells were washed twice with phosphate-buffered saline (PBS; Solarbio) and fixed with $4 \%$ paraformaldehyde for $30 \mathrm{~min}$ and then stained with $0.1 \%$ crystal violet hydrate solution for $20 \mathrm{~min}$. The number of colonies with $\geq 50$ cells was counted under an inverted microscope (Nikon, Tokyo, Japan) and calculated as: plate clone formation efficiency $=$ number of colonies $/$ number of cells inoculated x100.

In vitro 'wound' closure assay. SKOV-3 cells were plated in 6-well plates and treated with $0.5 \mu \mathrm{g} / \mu \mathrm{l} \mathrm{uPAg}-\mathrm{KPI}$ until cells reached confluence. A 'wound' was then created by scratching the surface of the well with a pipette tip. Following injury, cells were further cultured in serum-free IMDM with or without uPAg-KPI $(0.5 \mu \mathrm{g} / \mu \mathrm{l})$ for 24 and $48 \mathrm{~h}$. Cells were then photographed using a phase-contrast microscope (x100) and the wound closure was measured as previously described (16).

Tumor cell migration and invasion assay. In the present study, SKOV-3 cells were treated in the presence or absence of $0.5 \mu \mathrm{g} / \mu \mathrm{l} \mathrm{uPAg}$-KPI for two days, and tumor cell migration and invasion capacity were measured using the Transwell system (Corning) with or without Matrigel precoating (BD Biocoat ${ }^{\mathrm{TM}}$ Matrigel Invasion chamber with an $8-\mu \mathrm{m}$ filter), respectively. In brief, cells were trypsinized and resuspended in serum-free IMDM and placed in the upper chamber of a Transwell plate at a density of $2 \times 10^{4}$ cells/well, containing $0.5 \mu \mathrm{g} / \mu \mathrm{l}$ of uPAgKPI or control loading solution (PBS). The bottom chambers contained IMDM and 20\% FBS. Cells were incubated for $48 \mathrm{~h}$ in a humidified atmosphere with $95 \%$ air and $5 \% \mathrm{CO}_{2}$ at $37^{\circ} \mathrm{C}$. Non-migrated or invasive cells in the upper chamber were removed by wiping the upper side of the membrane with a cotton swab. Migrated or invading cells on the reverse side of the membrane were fixed with $4 \%$ paraformaldehyde and stained with $0.1 \%$ crystal violet for 15 min and counted under a light microscope at a magnification of $\mathrm{x} 200$.

Protein extraction and western blot analysis. SKOV-3 cells were plated onto a $10-\mathrm{cm}$ tissue culture dish and grown for $24 \mathrm{~h}$. uPAg-KPI $(0.5 \mu \mathrm{g} / \mu \mathrm{l})$ was then added to each dish and PBS (the solvent) was used as a vehicle control. Cells were incubated at $37^{\circ} \mathrm{C}$ for $0,12,24$ and $48 \mathrm{~h}$ and harvested and resuspended in ice-cold PBS (pH 7.4) containing 2 mM EDTA and $0.1 \%$ Triton $\mathrm{X}-100$. Collected cells were sonicated and centrifuged at $12,000 \mathrm{rpm}$ for $20 \mathrm{~min}$ at $4^{\circ} \mathrm{C}$ in order to remove 


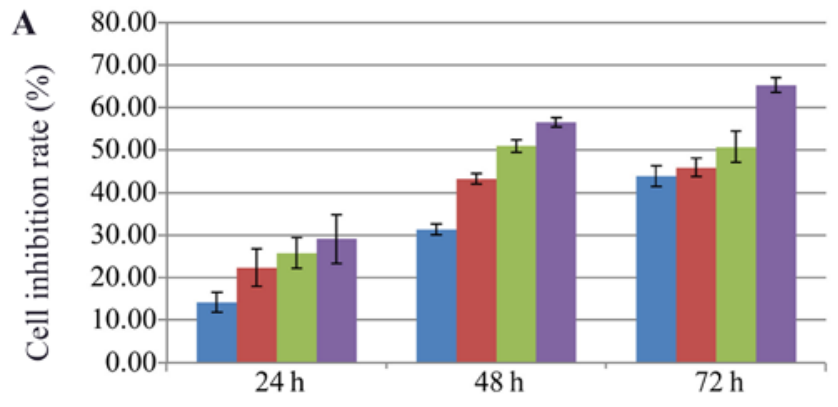

$=0.05 \equiv 0.1=0.5=1 \mathrm{uPAg}-\mathrm{KPI}$ concentration $(\mu \mathrm{g} / \mu \mathrm{l})$

B
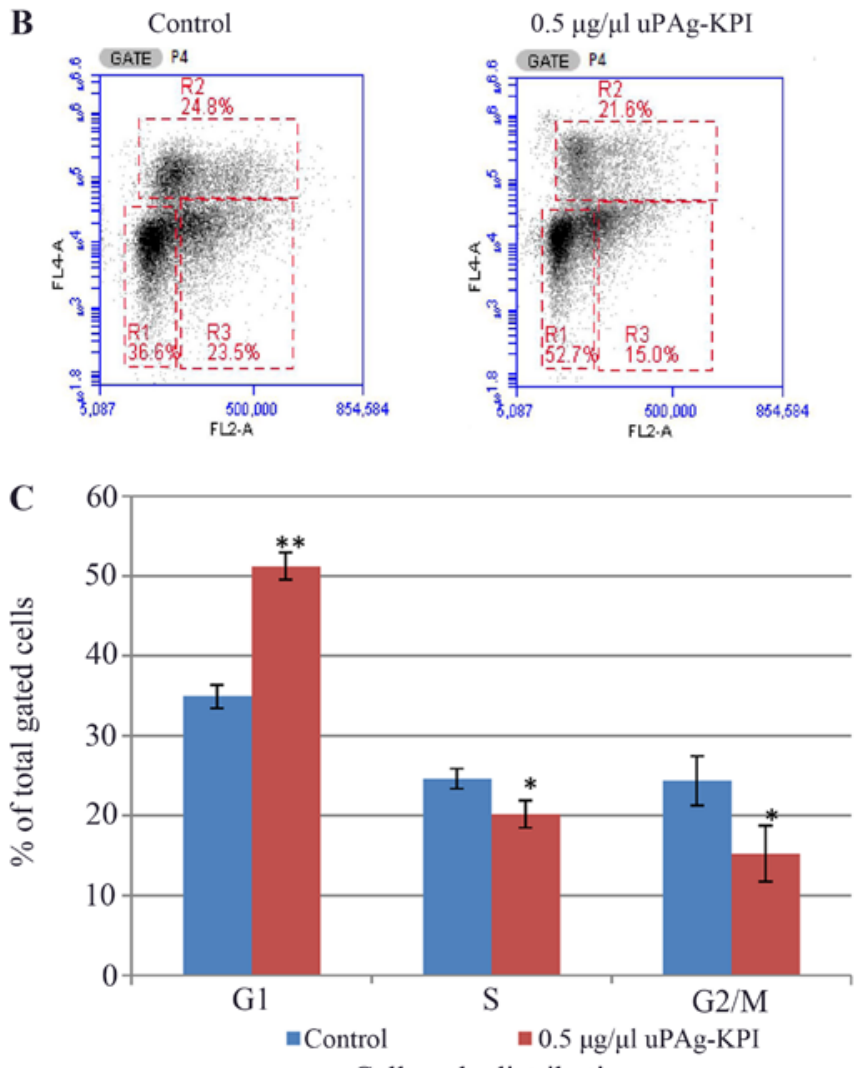

Cell cycle distribution

Figure 1. Effect of urokinase-type plasminogen activator (uPA)g-kunitz protease inhibitor (KPI) on inhibition of SKOV-3 cell viability. (A) Cell viability MTT assay. SKOV-3 cells were cultured with different concentrations of uPAg-KPI for up to $72 \mathrm{~h}$ and then subjected to MTT assay. The data are represented as the means \pm SD of three independent experiments. (B) Flow cytometric cell cycle analysis. Cells were grown and treated with or without uPAg-KPI $(0.5 \mu \mathrm{g} / \mu \mathrm{l})$ for $48 \mathrm{~h}$ and then subjected to flow cytometric cell cycle analysis. (C) Summarized data of (B) cell cycle distribution. The experiment was repeated three times. ${ }^{*} \mathrm{P}<0.05$ and ${ }^{* *} \mathrm{P}<0.01$.

cell debris. The supernatant was collected for determination of total protein concentration using a Pierce ${ }^{\mathrm{TM}}$ protein BCA assay kit (Thermo Fisher Scientific, Waltham, MA, USA) with bovine serum albumin (BSA) as a standard. Briefly, samples were electrophoresed and then transferred to polyvinylidene difluoride membrane using a semidry transfer system. Non-specific binding sites were blocked for $1 \mathrm{~h}$ in Tris-buffered saline, $\mathrm{pH}$ 7.6, containing 5\% dried skimmed milk. Blots were incubated with ERK1/2, p-ERK1/2, AKT and p-AKT antibodies overnight at $4^{\circ} \mathrm{C}$, then diluted with secondary antibody for $1 \mathrm{~h}$. After several washes, reactive bands were visualized using an ECL chemiluminescence detection kit (Thermo Fisher Scientific) (17).

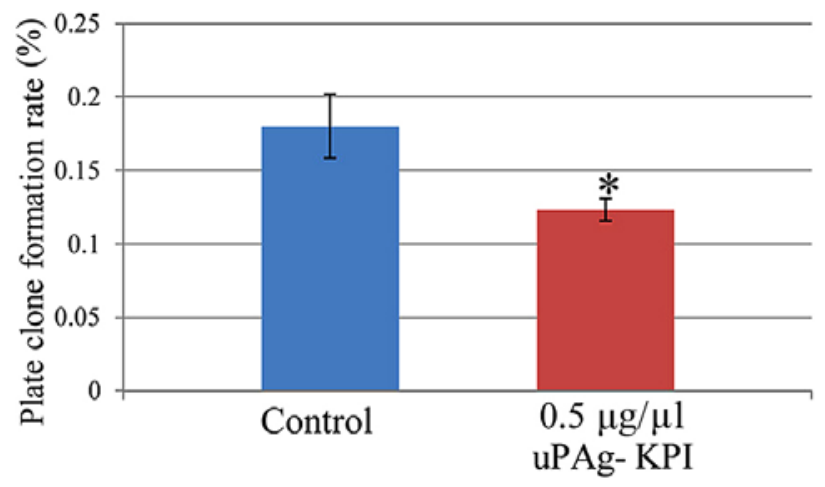

Figure 2. Effect of urokinase-type plasminogen activator (uPA)g-kunitz protease inhibitor (KPI) on the inhibition of SKOV-3 cell plate colony formation. Cells were grown and treated with $0.5 \mu \mathrm{g} / \mu \mathrm{l} \mathrm{uPAg}$-KPI for 14 days and the colony formation rate of the control and treatment groups was counted after staining with crystal violet hydrate solution. The data are summarized and presented as the means \pm SD of three independent experiments. ${ }^{*} \mathrm{P}<0.05$.

Statistical analysis. In the present study, all data are represented as the means $\pm \mathrm{SD}$ of three independent experiments. Statistical difference was evaluated using the Student's t-test, and a P-value $<0.05$ was considered to indicate a statistically significant difference. All statistical analyses were performed using SPSS, version 19 software (SPSS, Chicago, IL, USA) to compare the experimental versus control groups.

\section{Results}

Effects of uPAg-KPI on inhibition of SKOV-3 cell viability. In order to assess the effect of uPAg-KPI on the inhibition of ovarian cancer cell growth, we treated cells with various concentrations of uPAg-KPI for up to $72 \mathrm{~h}$ and performed the cell viability MTT assay. Our data demonstrated that uPAg-KPI markedly reduced cell viability in a dose- and time-dependent manner in SKOV-3 cells (Fig. 1A). The $\mathrm{IC}_{50}$ value of uPAg-KPI was $0.5 \mu \mathrm{g} / \mu \mathrm{l}$ in SKOV-3 cells following $48 \mathrm{~h}$ treatment. We thus selected $0.5 \mu \mathrm{g} / \mu \mathrm{l} \mathrm{uPAg}$-KPI for $48 \mathrm{~h}$ treatment for subsequent experiments. A reduction in cell viability by uPAg-KPI was also confirmed by Trypan blue dye exclusion (data not shown).

Following the aforementioned experiments, flow cytometric analysis (cell cycle distribution assay) demonstrated that cells treated with uPAg-KPI $(0.5 \mu \mathrm{g} / \mu \mathrm{l})$ for $48 \mathrm{~h}$ accumulated at the G1 phase of cell cycle (52.7 vs. $36.6 \%$ of control) (Fig. 1B and C). Moreover, the number of cells in the S and $\mathrm{G} 2 / \mathrm{M}$ phases declined (21.6 vs. $24.8 \%$ and 15.0 vs. $23.5 \%$ of control, respectively). These results demonstrated that uPAgKPI inhibited SKOV-3 cell proliferation (Fig. 1B and C).

Effects of uPAg-KPI on the inhibition of tumor cell colony formation. Considering uPAg-KPI has the propensity to affect cell proliferation in vitro, a plate colony formation assay was performed. The efficiency of plate colony formation indicated that there was a significant difference between cells treated with $0.5 \mu \mathrm{g} / \mu \mathrm{l}$ of uPAg-KPI compared to untreated control cells. The number of colonies after treatment was notably fewer compared to the controls (Fig. 2). The result, to an extent, further confirmed that treatment with uPAg-KPI reduced the proliferation of ovarian cancer cells. 

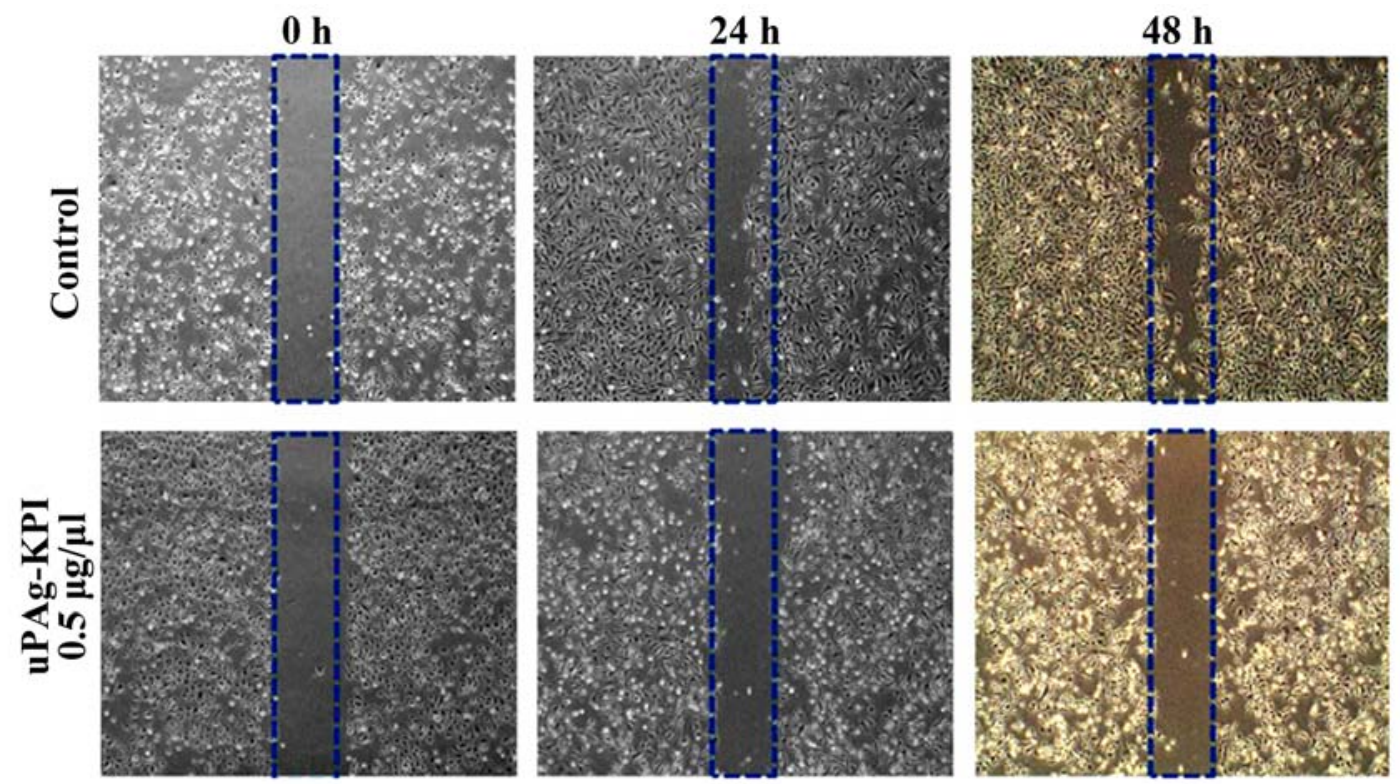

Figure 3. Effect of urokinase-type plasminogen activator (uPA)g-kunitz protease inhibitor (KPI) on the inhibition of SKOV-3 cell wound closure. Cells were grown and treated with $0.5 \mu \mathrm{g} / \mu 1 \mathrm{uPAg}-\mathrm{KPI}$ for 24 or $48 \mathrm{~h}$. When cells reached a confluent monolayer, a wound was created using a pipette tip, cell debris was rinsed away using ice-cold PBS and the remaining cells were cultured for 24 or $48 \mathrm{~h}$. The relative wound closure was photographed and measured using a phase-contrast microscope.

Effects of uPAg-KPI on the inhibition of SKOV-3 cell migration and invasive capacity. We analyzed the effects of uPAg-KPI on the migration and invasive capacity of SKOV-3 cells using the previously mentioned wound healing assay. As shown in Fig. 3, relative wound closure was decreased following treatment with uPAg-KPI $(0.5 \mu \mathrm{g} / \mu \mathrm{l})$ for 24 or $48 \mathrm{~h}$ compared to the controls.

Following this, we performed Transwell tumor cell migration and invasion assays and demonstrated that uPAg-KPI had a significant inhibitory effect on cell migration and invasion at the concentration $0.5 \mu \mathrm{g} / \mu \mathrm{l}$ (Fig. 4).

Effects of $u P A g-K P I$ on the regulation of ERK1/2 and AKT activity in SKOV-3 cells. After establishing the ability of uPAg-KPI to inhibit cell migration, we assessed the underlying molecular mechanisms of uPAg-KPI. Using western blot analysis, we demonstrated that treatment with uPAg-KPI suppressed p-ERK and p-AKT activity. However, no marked effects on the total levels of ERK1/2 and AKT proteins were noted (Fig. 5).

\section{Discussion}

Ovarian cancer is a highly metastatic type of cancer, and identification of the underlying molecular signaling pathways will help effectively control disease progression (18). Generally, degradation of the extracellular matrix is considered to be the first step of tumor invasion or metastasis. Activation of the uPA/uPAR/plasmin proteolytic signaling network plays a key role in extracellular matrix degradation. Previous studies using natural and synthetic uPA inhibitors have demonstrated abrogated tumor cell growth, invasion and metastasis due to inhibition of uPA serine protease activities $(19,20)$ and the ability of certain uPA antagonists (21-23) to block binding to uPAR on the tumor cell surface.

In our previous study, we constructed uPAg-KPI, which contained uPA GFD conjugated with a kunitz protease inhibitor (KPI) domain that is present in the amyloid betaprotein precursor (APP). Our previous data demonstrated that this fusion protein inhibited serine protease activity in vitro (15). Thus, in the present study, we assessed the effects of this fusion protein uPAg-KPI on the regulation of ovarian cancer cell phenotypes and protein expression. We found that uPAg-KPI treatment reduced the viability of ovarian cancer cells in a concentration and time-dependent manner and arrested tumor cells at the G1/G0 phase of the cell cycle. The $\mathrm{IC}_{50}$ of uPAg-KPI was $0.5 \mu \mathrm{g} / \mu \mathrm{l}$ after $48 \mathrm{~h}$ treatment, and treatment of ovarian cancer cells with this concentration inhibited tumor cell colony formation, wound healing, and tumor cell migration and invasive capacity. Molecularly, uPAg-KPI suppressed the activity of ERK $1 / 2$ and AKT proteins. Thus, we demonstrated that this novel uPAg-KPI fusion protein exerted antitumor activity in ovarian cancer SKOV-3 cells in vitro by regulation of ERK and AKT signaling.

UPA was originally isolated from human urine and is present in the bloodstream and the extracellular matrix (24). The primary physiological substrate of uPA is plasminogen, and activation of plasmin triggers a proteolytic cascade to promote thrombolysis or extracellular matrix degradation. Altered expression or altered activity of uPA is linked to a variety of vascular diseases and cancers $(25,26)$. Extracellular matrix degradation, following plasminogen activation has been shown to induce tumor cell tissue invasion and metastasis, whereas inhibition of uPA activity or expression has been used as an anticancer agent $(27,28)$. Indeed, Mesupron $^{\circledR}$, a small molecule serine protease inhibitor developed by WILEX, has been used in clinical trials (http://www.wilex. de/portfolio/mesupron/phase-i-ii-mit-mesupron/). Studies have suggested that the drug appears to be safe when combined with chemotherapy in cases of breast cancer (http://www.wilex.de/ portfolio/mesupron/phase-i-ii-mit-mesupron/).

In the present study, we found that the fusion protein uPAg-KPI not only demonstrated the ability to inhibit tumor 

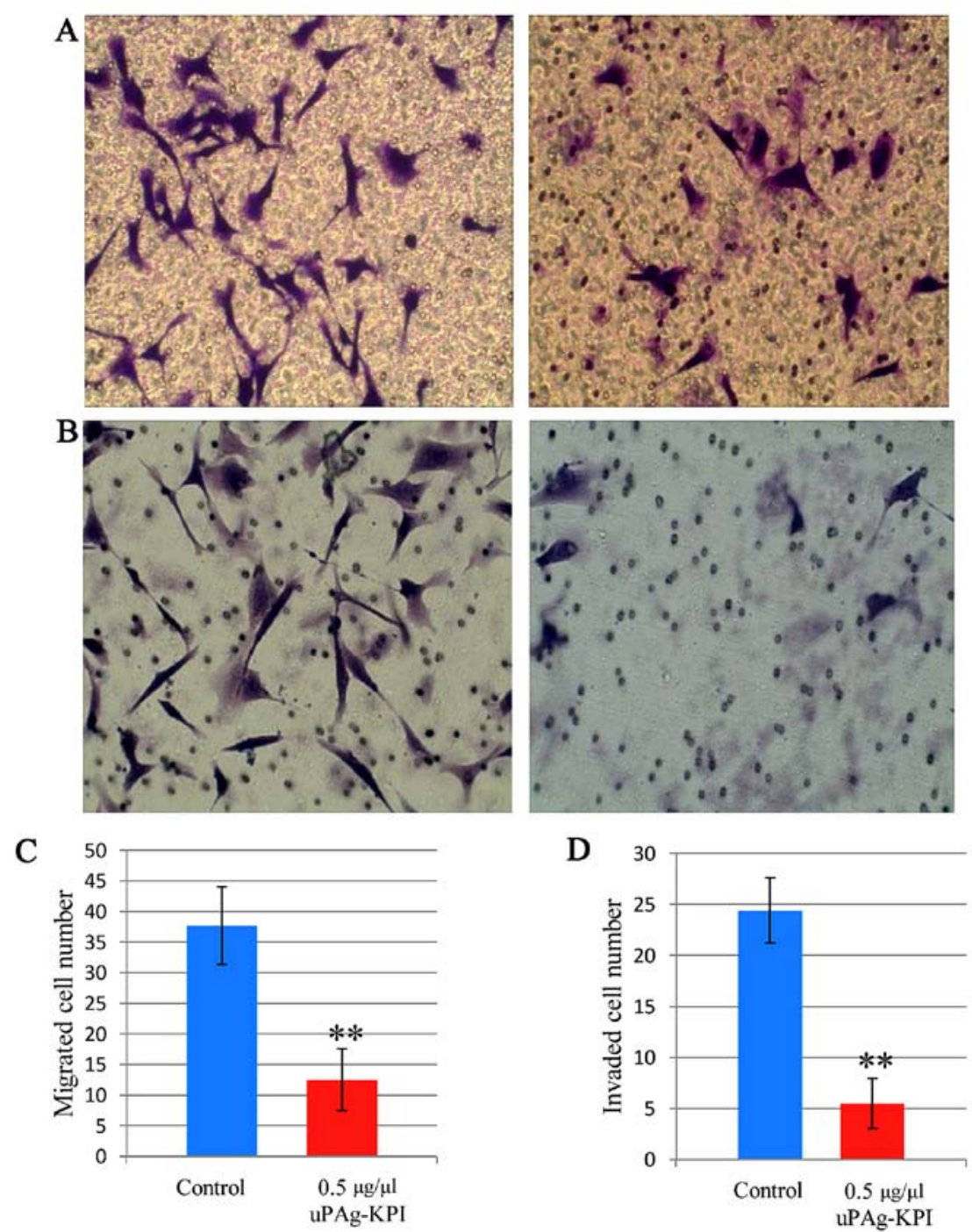

Figure 4. Effect of urokinase-type plasminogen activator (uPA)g-kunitz protease inhibitor (KPI) on inhibition of SKOV-3 cell migration and invasion (A and C) Cell migration assay. Cells at a density of $2 \times 10^{4}$ cells $/ 100 \mu \mathrm{l}$ were plated in the upper chamber in the absence or presence of $\mathrm{uPAg}-\mathrm{KPI}(0.5 \mu \mathrm{g} / \mu \mathrm{l})$, and the bottom chambers were filled with regular IMDM/10\% FBS. Cells were cultured for $48 \mathrm{~h}$. At the end of the experiment, cells which had migrated into the bottom filter were counted under a phase-contrast microscope (x200) after staining with $1 \%$ crystal violet. ${ }^{* *} \mathrm{P}<0.01$. (B and D) Transwell tumor cell invasion assay. Transwell filters were pre-coated with Matrigel and the rest of the procedures were the same as for the Transwell tumor cell migration assay.

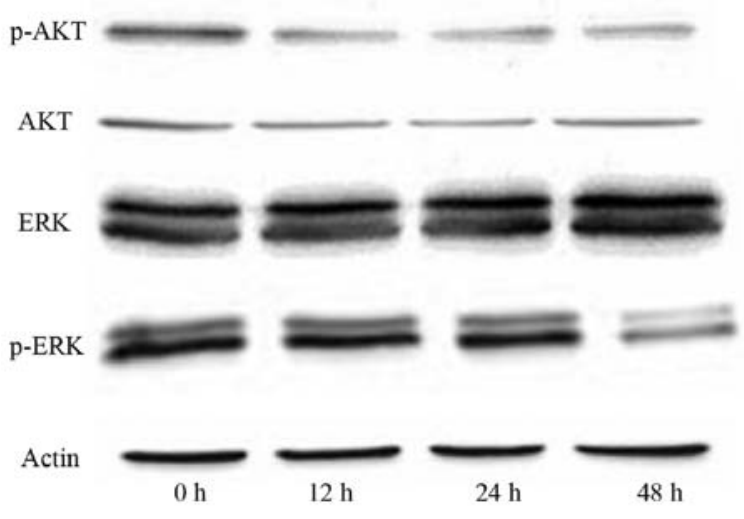

Figure 5. Effect of urokinase-type plasminogen activator (uPA)g-kunitz protease inhibitor (KPI) protein on the regulation of AKT, p-AKT, extracellular signalregulated kinase (ERK)1/2, and p-ERK1/2 protein expression in SKOV-3 cells, as measured by western blot analysis. SKOV-3 cells were grown and treated with $0.5 \mu \mathrm{g} / \mu \mathrm{l} \mathrm{uPAg}$-KPI for $0,12,24$ and $48 \mathrm{~h}$ and then subjected to western blot analysis to measure the AKT, p-AKT, ERK1/2 and p-ERK1/2 protein levels. The experiments were repeated three times with similar results. cell growth, but also inhibited tumor cell invasion and metastasis. It is envisioned that futire in vivo studies will assess the effectiveness of this fusion protein uPAg-KPI in animals before clinical trials. However, the uPA signal transduction pathway is complex, and there is a plethora of combining pathways. For example, previous studies have shown that the uPA/uPAR signaling cascade may be at the intersection of multiple tumor invasion and metastasis-related signaling molecules or pathways (29-32). In addition to activating extracellular matrix degradation, the UPA/uPAR system also activates Src, Raf, FAK, ERK or MAPK signaling pathways, which play an important role in tumor progression (33-35). With respect to the induction of tumor cell proliferation, previous studies have shown that uPA induced a cascade of several cell proliferation signaling pathways, such as the signal transducer and activator of transcription (Stat3) pathway, ERK1/2 pathway and the phosphatidylinositol 3-kinase/protein kinase B (PI3K/AKT) pathway (36-39). In order to investigate the possible mechanisms by which uPAg-KPI induced cell growth arrest and 
inhibition of tumor cell invasion, the present study detected the level of ERK, p-ERK, AKT and p-AKT proteins and found that uPAg-KPI suppressed the expression of phosphorylated ERK1/ERK2 and AKT. These two pathways have previously been shown to regulate cell growth and invasion $(40,41)$. Thus, the data obtained from the present study suggest that uPAg-KPI binds to membrane-anchored UPAR and restrains plasminogen activation on the tumor cell surface. This blocks the ERK and AKT signaling pathways and thus significantly decreases tumor growth and invasion. However, further investigation is required in order to elucidate how exactly uPAg-KPI suppresses phosphorylation and the activity of ERK1/ERK2 and AKT proteins.

\section{Acknowledgements}

This study was supported in part by grants from the National Natural Science Foundation of China (nos. 81302242 and 81272875), the Jilin Provincial Science and Technology Funds (nos. 20150204007YY, 20130102094JC, 20140204022YY, $20150204041 Y Y$ and $20130727039 Y Y)$, the Jilin provincial development and Reform Commission Funds (no. 2013C026-3).

\section{References}

1. Stewart BW, Kleihues P (eds): World Cancer Report. IARC press, Lyon, 2003.

2. Mao Y, Xu J, Li Z, Zhang N, Yin H and Liu Z: The role of nuclear $\beta$-catenin accumulation in the Twist2-induced ovarian cancer EMT. PLoS One 8: e78200, 2013.

3. Fazioli $\mathrm{F}$ and Blasi F: Urokinase-type plasminogen activator and its receptor: new targets for anti-metastatic therapy? Trends Pharmacol Sci 15: 25-29, 1994.

4. Mekkawy AH, Pourgholami MH and Morris DL: Involvement of urokinase-type plasminogen activator system in cancer: an overview. Med Res Rev 34: 918-956, 2014.

5. Andreasen PA, Kjøller L, Christensen L and Duffy MJ: The urokinase-type plasminogen activator system in cancer metastasis: a review. Int J Cancer 72: 1-22, 1997.

6. Kwaan HC: The plasminogen-plasmin system in malignancy. Cancer Metastasis Rev 11: 291-311, 1992.

7. Berkenblit A, Matulonis UA, Kroener JF, Dezube BJ, Lam GN, Cuasay LC, Brünner N, Jones TR, Silverman MH and Gold MA: A6, a urokinase plasminogen activator (uPA)-derived peptide in patients with advanced gynecologic cancer: a phase I trial. Gynecol Oncol 99: 50-57, 2005.

8. Ghamande SA, Silverman MH, Huh W, Behbakht K, Ball G, Cuasay L, Würtz SO, Brunner N and Gold MA: A phase 2, randomized, double-blind, placebo-controlled trial of clinical activity and safety of subcutaneous A6 in women with asymptomatic CA125 progression after first-line chemotherapy of epithelial ovarian cancer. Gynecol Oncol 111: 89-94, 2008.

9. Gold MA, Brady WE, Lankes HA, Rose PG, Kelley JL, De Geest K, Crispens MA, Resnick KE and Howell SB: A phase II study of a urokinase-derived peptide (A6) in the treatment of persistent or recurrent epithelial ovarian, fallopian tube, or primary peritoneal carcinoma: a Gynecologic Oncology Group study. Gynecol Oncol 125: 635-639, 2012.

10. Heinemann V, Ebert MP, Laubender RP, Bevan P, Mala C and Boeck S: Phase II randomised proof-of-concept study of the urokinase inhibitor upamostat (WX-671) in combination with gemcitabine compared with gemcitabine alone in patients with non-resectable, locally advanced pancreatic cancer. Br J Cancer 108: 766-770, 2013.

11. Chen H, Hao J, Wang L and Li Y: Coexpression of invasive markers (uPA, CD44) and multiple drug-resistance proteins (MDR1, MRP2) is correlated with epithelial ovarian cancer progression. Br J Cancer 101: 432-440, 2009.

12. Wang L, Madigan MC, Chen H, Liu F, Patterson KI, Beretov J, O'Brien PM and Li Y: Expression of urokinase plasminogen activator and its receptor in advanced epithelial ovarian cancer patients. Gynecol Oncol 114: 265-272, 2009.
13. Dorn J, Harbeck N, Kates R, Gkazepis A, Scorilas A, Soosaipillai A, Diamandis E, Kiechle M, Schmalfeldt B and Schmitt M: Impact of expression differences of kallikrein-related peptidases and of UPA and PAI-1 between primary tumor and omentum metastasis in advanced ovarian cancer. Ann Oncol 22: 877-883, 2011.

14. Salameh MA, Robinson JL, Navaneetham D, Sinha D, Madden BJ, Walsh PN and Radisky ES: The amyloid precursor protein/protease nexin $2 \mathrm{Kunitz}$ inhibitor domain is a highly specific substrate of mesotrypsin. J Biol Chem 285: 1939-1949, 2010.

15. Zhao L and Yan W: Expression and identification of recombinant humanuPA17-KPI in Pichia pastoris. Chin J Lab Diagn 14: $1685-1688,2010$

16. Lai KC, Huang AC, Hsu SC, Kuo CL, Yang JS, Wu SH and Chung JG: Benzyl isothiocyanate (BITC) inhibits migration and invasion of human colon cancer HT2 9 cells by inhibiting matrix metalloproteinase-2/-9 and urokinase plasminogen (uPA) through PKC and MAPK signaling pathway. J Agric Food Chem 58: 2935-2942, 2010.

17. Lin Y, Cui M, Xu T, Yu W and Zhang L: Silencing of cyclooxygenase-2 inhibits the growth, invasion and migration of ovarian cancer cells. Mol Med Rep 9: 2499-2504, 2014.

18. Vergara D, Merlot B, Lucot JP, Collinet P, Vinatier D, Fournier I and Salzet M: Epithelial-mesenchymal transition in ovarian cancer. Cancer Lett 291: 59-66, 2010.

19. Evans DM and Lin PL: Suppression of pulmonary metastases of rat mammary cancer by recombinant urokinase plasminogen activator inhibitor. Am Surg 61: 692-696, discussion 696-697, 1995.

20. Praus M, Wauterickx K, Collen D and Gerard RD: Reduction of tumor cell migration and metastasis by adenoviral gene transfer of plasminogen activator inhibitors. Gene Ther 6: 227-236, 1999.

21. Guo Y, Higazi AA, Arakelian A, Sachais BS, Cines D, Goldfarb RH, Jones TR, Kwaan H, Mazar AP and Rabbani SA: A peptide derived from the nonreceptor binding region of urokinase plasminogen activator (uPA) inhibits tumor progression and angiogenesis and induces tumor cell death in vivo. FASEB J 14: 1400-1410, 2000.

22. Guo Y, Mazar AP, Lebrun JJ and Rabbani SA: An antiangiogenic urokinase-derived peptide combined with tamoxifen decreases tumor growth and metastasis in a syngeneic model of breast cancer. Cancer Res 62: 4678-4684, 2002.

23. Ploug M, Østergaard S, Gårdsvoll H, Kovalski K, Holst-Hansen C, Holm A, Ossowski L and Danø K: Peptide-derived antagonists of the urokinase receptor. Affinity maturation by combinatorial chemistry, identification of functional epitopes, and inhibitory effect on cancer cell intravasation. Biochemistry 40: 12157-12168, 2001.

24. Zaravinos A: The regulatory role of MicroRNAs in EMT and cancer. J Oncol 2015: 865816, 2015.

25. Chandrasekar N, Mohanam S, Gujrati M, Olivero WC, Dinh DH and Rao JS: Downregulation of uPA inhibits migration and PI3k/ Akt signaling in glioblastoma cells. Oncogene 22: 392-400, 2003.

26. Wang Q, Wang Y, Zhang Y, Zhang Y and Xiao W: The role of UPAR in epithelial-mesenchymal transition in small airway epithelium of patients with chronic obstructive pulmonary disease. Respir Res 14: 67, 2013.

27. Jankun J and Skrzypczak-Jankun E: Molecular basis of specific inhibition of urokinase plasminogen activator by amiloride. Cancer Biochem Biophys 17: 109-123, 1999.

28. Matthews H, Ranson M and Kelso MJ: Anti-tumour/metastasis effects of the potassium-sparing diuretic amiloride: an orally active anti-cancer drug waiting for its call-of-duty? Int $\mathbf{J}$ Cancer 129: 2051-2061, 2011.

29. Lester RD, Jo M, Montel V, Takimoto S and Gonias SL: uPAR induces epithelial-mesenchymal transition in hypoxic breast cancer cells. J Cell Biol 178: 425-436, 2007.

30. Liu SQ, Huang JA, Qin MB, Su YJ, Lai MY, Jiang HX and Tang GD: Sphingosine kinase 1 enhances colon cancer cell proliferation and invasion by upregulating the production of MMP-2/9 and uPA via MAPK pathways. Int J Colorectal Dis 27: 1569-1578, 2012

31. Chou RH, Hsieh SC, Yu YL, Huang MH, Huang YC and Hsieh YH: Fisetin inhibits migration and invasion of human cervical cancer cells by down-regulating urokinase plasminogen activator expression through suppressing the p38 MAPK-dependent NF- $\kappa$ B signaling pathway. PLoS One 8: e71983, 2013 
32. Jo M, Lester RD, Montel V, Eastman B, Takimoto S and Gonias SL: Reversibility of epithelial-mesenchymal transition (EMT) induced in breast cancer cells by activation of urokinase receptor-dependent cell signaling.J Biol Chem 284: 22825-22833, 2009.

33. Blasi F and Sidenius N: The urokinase receptor: focused cell surface proteolysis, cell adhesion and signaling. FEBS Lett 584: 1923-1930, 2010.

34. Eastman BM, Jo M, Webb DL, Takimoto S and Gonias SL: A transformation in the mechanism by which the urokinase receptor signals provides a selection advantage for estrogen receptorexpressing breast cancer cells in the absence of estrogen. Cell Signal 24: 1847-1855, 2012.

35. Nowicki TS, Zhao H, Darzynkiewicz Z, Moscatello A, Shin E, Schantz S, Tiwari RK and Geliebter J: Downregulation of uPAR inhibits migration, invasion, proliferation, FAK/PI3K/Akt signaling and induces senescence in papillary thyroid carcinoma cells. Cell Cycle 10: 100-107, 2011.

36. Gogineni VR, Gupta R, Nalla AK, Velpula KK and Rao JS: uPAR and cathepsin B shRNA impedes TGF- $\beta 1$-driven proliferation and invasion of meningioma cells in a XIAP-dependent pathway. Cell Death Dis 3: e439, 2012.
37. Shetty S, Rao GN, Cines DB and Bdeir K: Urokinase induces activation of STAT3 in lung epithelial cells. Am J Physiol Lung Cell Mol Physiol 291: L772-L780, 2006.

38. Stewart AG, Xia YC, Harris T, Royce S, Hamilton JA and Schuliga M: Plasminogen-stimulated airway smooth muscle cell proliferation is mediated by urokinase and annexin A2, involving plasmin-activated cell signalling. Br J Pharmacol 170: 1421-1435, 2013.

39. Ulisse S, Baldini E, Sorrenti S and D'Armiento M: The urokinase plasminogen activator system: a target for anti-cancer therapy. Curr Cancer Drug Targets 9: 32-71, 2009.

40. Santarpia L, Lippman SM and El-Naggar AK: Targeting the MAPK-RAS-RAF signaling pathway in cancer therapy. Expert Opin Ther Targets 16: 103-119, 2012.

41. Romano G: The role of the dysfunctional akt-related pathway in cancer: establishment and maintenance of a malignant cell phenotype, resistance to therapy, and future strategies for drug development. Scientifica (Cairo) 2013: 317186, 2013. 